\title{
Multiple Perspective of Cloud Computing Adoption Determinants in Higher Education a Systematic Review
}

DOI:

10.4018/IJCAC.2019070106

Document Version

Final published version

Link to publication record in Manchester Research Explorer

\section{Citation for published version (APA):}

Ali, M. B. (2019). Multiple Perspective of Cloud Computing Adoption Determinants in Higher Education a Systematic Review. International Journal of Cloud Applications and Computing, 9(3), 89-109.

https://doi.org/10.4018/IJCAC.2019070106

\section{Published in:}

International Journal of Cloud Applications and Computing

\section{Citing this paper}

Please note that where the full-text provided on Manchester Research Explorer is the Author Accepted Manuscript or Proof version this may differ from the final Published version. If citing, it is advised that you check and use the publisher's definitive version.

\section{General rights}

Copyright and moral rights for the publications made accessible in the Research Explorer are retained by the authors and/or other copyright owners and it is a condition of accessing publications that users recognise and abide by the legal requirements associated with these rights.

\section{Takedown policy}

If you believe that this document breaches copyright please refer to the University of Manchester's Takedown Procedures [http://man.ac.uk/04Y6Bo] or contact uml.scholarlycommunications@manchester.ac.uk providing relevant details, so we can investigate your claim.

\section{OPEN ACCESS}




\title{
Multiple Perspective of Cloud Computing Adoption Determinants in Higher Education a Systematic Review
}

Mohammed Banu Ali, Alliance Manchester Business School, University of Manchester, Innovation Management and Policy Division, UK

\begin{abstract}
Cloud computing has become a major talking point in recent times. An innovation such as cloud computing for higher education institutions (HEI) can be a cost effective means to operate their IT systems effectively without having to spend vast amounts of money on developing their IT infrastructure. HEIs also face the burden of several challenges e.g. limited infrastructure resources and IT budget, as well as limited teaching staff, technical experts, and IT skilled personnel. With support from a systematic literature review approach, this article identifies the key determinants of cloud adoption from a technological, organisational, environmental and personal perspectives. A total of 17 cloud adoption studies in the HEI context and their respected models from the period of 2012 to 2017 are reviewed and discussed. The findings suggest a lack of cloud adoption studies in the HEI domain from multiple perspectives, particularly in relation to the wider socio-technical concerns related to cloud adoption and future studies related to this research gap are deliberated.
\end{abstract}

\section{KEYWORDS}

Cloud Computing Adoption, Cloud Computing, Cloud Determinants, Higher Education Institutions (HEI), Multiple Perspectives

\section{INTRODUCTION}

Cloud computing is a highly prevalent technology for the delivery of IT-driven services and infrastructure owing to developments in a number of technologies, including the internet, hardware and distributed computing (Bhowmik, 2017). Recently, organisations have begun to shift from traditional ICTs to a cloud solution owing to the flexibility, scalability and agility of the technology, as well as the economic benefits the cloud can bring by adopting the technology (Armbrust et al., 2010). The National Institute of Standards and Technology (NIST) defines cloud computing as a ubiquitous and flexible data centralising tool that comprises of three service models: Software as a Service (SaaS), Platform as a Service (PaaS) and Infrastructure as a Service (IaaS) and four deployment models: private cloud, public cloud, community cloud, and hybrid cloud (Mell \& Grance, 2011). Recently, cloud adoption has been the center of attention in the education domain, particularly in Higher Education Intuitions (HEIs). 
In HEIs, cloud computing has become a highly popular paradigm. In view of Sultan (2011), cloud computing allows academic and non-academic staff, such as teachers and researchers in HEIs to access a wide pool of services and resources offered by the cloud service provider. HEIs that adopt the cloud can allow for virtualisation of IT resources, such as operating systems, servers, storage devices, or network resources (Odeh et al., 2017).

Several studies highlight the adoption of an educational cloud and associated cloud applications (Mircea \& Andreescu, 2011; Sabi et al., 2016; Sultan, 2010). The aim of an educational cloud is to harness the power of multiple networked computers that enable collaboration among researchers and students. Cloud computing comprises of various unique and interesting characteristics to encourage cloud computing adoption by HEIs. Lian et al. (2014) outlines such characteristics as follows:

Computing resource virtualisation: Remote usage of computing resources so end users can access computing resources from various devices anytime and anywhere. High performance: Super computing power capable of massive data analysis capability, and large data storage capacity provision; Reduced cost: Acquisition and maintaining required resources or services onsite thereby reducing management costs in the long run; and Scalability: Dynamic scalability based on demand, thus requiring HEIs to only invest in required infrastructure and services (Alharthi et al., 2015; Mokhtar et al., 2014; Mokhtar et al., 2016; Rao \& Selvamani, 2015).

Currently, HEIs face the burden of several challenges based on the provision of quality education. These challenges are summarised as follows:

- Existing learning and teaching resources are distributed across education institutions not on the basis of their needs but on personal reasons or rationales, thus leading to unbalanced development among HEIs;

- Limited funding to support HEIs' education and training needs in terms of infrastructure and accessibility of placements for prospective students;

- Paucity of technical expertise to support, maintain, and operate existing infrastructure in particular educational institutions;

- Qualified educators are currently located in a few specific areas; thus, imbalanced distribution of expertise among the institutions occurs.

Given the benefits of cloud computing to HEIs, Ercan (2010) found that cloud computing adoption in the education is marginal, accounting for only $4 \%$ of technological adoptions within the sector. The influencing determinants that affect HEIs' decision to adopt cloud computing should be understood to discover the main causes and rationales behind the adoption. This understanding can assist HEIs planning to adopt cloud computing to be well prepared and well planned. As a result, cloud computing adoption could potentially remedy the challenges HEIs face in utilising the traditional computing approach. Cloud computing adoption in HEIs could also improve education provisions to the current students in particular, as well as increase the literacy levels in the long run.

This paper aims to review empirical and non-empirical studies on cloud computing adoption, identify the influencing determinants (aspects) of cloud computing adoption, and categorise aspects from a technological, organisational, environmental and personal perspective.

\section{MOTIVATION}

Today, cloud computing is more prevalent than ever before. This owes to the innovation's ability to delivery ubiquitous services to its end-users, thus leading to major developments in the innovation across various sectors ranging from healthcare to education. As a result, the cloud has also emerged in not only developed countries, but also developing countries (Okezie et al., 2012). This prompts the need to explore current research that helps to understand and provide solutions for numerous cloud 
computing problems. Certainly, some researchers have explored the existing literature concerning various cloud computing topics in a wide range of contexts e.g. adoption, implementation and usage in small medium enterprises and healthcare organisations (Ammurathavalli \& Ramesh, 2014; Bhatt \& Peddoju, 2016; Carcary et al., 2014; Chang, 2015), most of which mostly focus on the technological perspective and often ignore the wider social perceptive, namely the impacts on organisations and stakeholders. In particular, cloud adoption has recently attracted many areas of education, particularly higher education with Higher Education Institutions (HEIs) starting to adopt the innovation (Singh \& Baheti, 2017).

However, cloud adoption rates in higher education are still relatively low (Ercan, 2010). Also, there is a paucity of studies that offer a systematic review of existing cloud adoption literature from multiple perspectives, particularly in higher education institutions (HEIs). Therefore, this paper aims to explore and evaluate existing literature pertaining the key determinants of cloud service adoption in the higher education context from a technological, organisational, environmental and personal perspective by employing a systematic review method. This systematic research will help to highlight the influencing determinants of cloud computing services from multiple perspectives, as well as the gaps in the existing literature and areas for future research.

\section{THEORIES OF ICT INNOVATION ADOPTION}

Theories of innovation adoption can be ontologically grouped into two distinct areas of analysis: micro (individual) and macro level (organisational). For the macro level, a number of technological adoption and acceptance theories are available. Venkatesh et al. (2003) highlights several models and theories relevant to the adoption and acceptance of innovations, such as the technology acceptance model (TAM), theory of planned behaviour (TPB), theory of reasoned action (TRA) and unified theory of acceptance and use of technology (UTAUT) (Venkatesh \& Bala, 2008).

The aforementioned models serve to ascertain the determinants that influence user adoption and acceptance and usage behaviour. Kim et al. (2011) highlighted several models and theories, such as TRA, TAM, TPB, Technology Acceptance Model 2, and UTAUT which are used to explore and understand ICT adoption behaviours from a personal or individualistic perspective. From a technological, organisational and environmental perspective, TOE and DOI are used to explore and understand technological adoption within the organisational context (Gangwar et al., 2015; Scholten, 2017).

\section{RESEARCH METHOD}

There are countless methods that can support a given research study, whether it be a research methodology to conduct empirical research or methods of conducting an extensive literature survey. For empirical studies, methods include qualitative, quantitative and mix method research. However, this paper does not intend to obtain data empirically or from primary sources, but rather from existing secondary sources. So this paper is geared towards conducting a literature survey. This idea is inspired by the growing plethora of emerging literature in the cloud computing domain, particularly in the HEI context in terms of supporting teaching, management and research practices. Furthermore, this paper aimed to unearth a potential literature gap which has been overlooked in the existing literature and ultimately make a clear theoretical contribution.

For that reason, this paper adopts a systematic literature review (SLR) approach. This is a process of identifying, assessing and interpreting all available and appropriate literature to answer specific research questions. Why systematic literature review? This is a type of literature review that aims to garner and critically review various research studies. This method helps to accurately synthesise existing literature about a given topic according to a specific procedure and research process that is expected to be reported in a way that the target audience can understand (Kitchenham 
\& Charters, 2007). Prior researchers have deliberated a method for literature review to confine a systematic fault, reduce chance effects and enhance data analysis legitimacy (Jafari Navimipour \& Charband, 2016), all of which build a strong case to conduct a systematic literature review. This also helps to obtain trustworthy results that help to build the foundation for drawing meaningful conclusions (Soltani \& Navimipour, 2016).

The following section summarises the SLR for conducting a wide analysis of the cloud adoption determinants in HEIs. Then, the search process is defined, comprising of the article selection process and classification. Finally, the research questions are defined. Therefore, this section aims to set the boundaries of the paper and scope of the reviewed studies.

\subsection{Selection Process}

This paper follows guidelines from Webster and Watson and Kitchenham and Charters method of conducting SLRs (Kitchenham \& Charters, 2007; Webster \& Watson, 2002). Our SLR is concept-centric, since it aims to classify studies according to technological, organisational, environmental and personal perspectives of the key determinants influencing cloud computing adoption in HEIs.

Several online databases were selected to find relevant research studies, namely Science Direct, Emerald, IEEE Xplore, Springer link, AISel and ProQuest, where keywords, such as "cloud computing" with "adoption," "diffusion," OR "acceptance," AND "higher education" were used as part of the search procedure. The scope of the search were recent studies from 2012-2017. Inclusion criteria involved selecting behavioural studies that investigate and gather empirical data, non-empirical or literature-based studies (e.g. systematic reviews and model-based studies), studies that focus on cloud computing adoption in the education sector and English written papers. Exclusion criteria involved studies that do not explore cloud adoption determinants, implementation studies and non-English papers. Moreover, 17 papers were included in the review (see Table 1). Table 2 summarises the search details and results according to our aforementioned criteria.

This paper identifies and classifies each determinant into four distinct groups: technological, organisational, environmental and personal. Technological determinants represent the internal and external technologies appropriate for HEIs; organisational determinants represent a firm's characteristics and resources that support or hinder innovation adoption; environmental determinants represent the external factors to the higher education that influence cloud computing adoption; and personal determinants represent individual characteristics, such as behaviour, intention, attitude, and firm interaction.

Moreover, this paper defined the following research questions to determine the content and structure of the SLR: 1) What are the technical determinants contributing to cloud computing adoption in HEIs? 2) What are the organisational determinants contributing to cloud computing adoption in HEIs? 3) What are the environmental determinants contributing to cloud computing adoption in HEIs? 4) What are the personal determinants contributing to cloud computing adoption in HEIs?

\section{MODEL TO CLASSIFY CLOUD ADOPTION DETERMINANTS}

This paper proposes a model that considers multiple perspectives, such as technological, organisational, environmental and personal determinants that influence cloud adoption. The information retained from the systematic review helped to expand the proposed model to include the most significant determinants influencing cloud computing adoption in higher education. In addition, the model served as a guide to categorise each study according to the aforementioned perspectives, which made up the main contribution of the paper. These perspectives were inspired by a number of adoption models, including TAM (Davis et al., 1989), DOI (Rogers, 2010) and TOE (Tornatzky et al., 1990). Figure 1 illustrates the perspectives. 
Table 1. Selected studies

\begin{tabular}{|c|c|c|}
\hline Author & Country & Title \\
\hline Amron et al. (2017) & Malaysia & A Review on Cloud Computing Acceptance Factors. \\
\hline Jawad et al. (2017) & Iraq & $\begin{array}{l}\text { Cloud Computing Adoption by Higher Education Institutions of Iraq: } \\
\text { An Empirical Study. }\end{array}$ \\
\hline Sabi et al. (2017) & $\begin{array}{l}\text { Sub-Saharan } \\
\text { Africa }\end{array}$ & $\begin{array}{l}\text { A cross-country model of contextual factors impacting cloud computing } \\
\text { adoption at universities in sub-Saharan Africa. }\end{array}$ \\
\hline $\begin{array}{l}\text { Shana and Abulibdeh } \\
\text { (2017) }\end{array}$ & $\begin{array}{l}\text { United Arab } \\
\text { Emirates }\end{array}$ & $\begin{array}{l}\text { Cloud Computing Issues for Higher Education: Theory of Acceptance } \\
\text { Model. }\end{array}$ \\
\hline Tariq et al. (2017) & Pakistan & $\begin{array}{l}\text { Factors influencing the Cloud Computing adoption in Higher Education } \\
\text { Institutions of Punjab, Pakistan. }\end{array}$ \\
\hline Almazroi et al. (2016) & Saudi Arabia & $\begin{array}{l}\text { Cloud for e-Learning: Determinants of Its Adoption by University } \\
\text { Students in a Developing Country. }\end{array}$ \\
\hline $\begin{array}{l}\text { Bhatiasevi and Naglis } \\
\text { (2016) }\end{array}$ & Thailand & $\begin{array}{l}\text { Investigating the structural relationship for the determinants of cloud } \\
\text { computing adoption in education. }\end{array}$ \\
\hline Mokhtar et al. (2016) & Malaysia & $\begin{array}{l}\text { Identifying the determinants of cloud computing adoption in higher } \\
\text { education institutions. }\end{array}$ \\
\hline Shiau and Chau (2016) & China & $\begin{array}{l}\text { Understanding behavioural intention to use a cloud computing } \\
\text { classroom: A multiple model comparison approach. }\end{array}$ \\
\hline Yuvaraj (2016) & India & $\begin{array}{l}\text { Determining factors for the adoption of cloud computing in developing } \\
\text { countries: A case study of Indian academic libraries. }\end{array}$ \\
\hline Alharthi et al. (2015) & $\begin{array}{l}\text { United } \\
\text { Kingdom }\end{array}$ & $\begin{array}{l}\text { An overview of cloud services adoption challenges in higher education } \\
\text { institutions. }\end{array}$ \\
\hline Dawson (2015) & United States & $\begin{array}{l}\text { Factors of technology adoption and their relationship to cloud } \\
\text { computing adoption in United States higher education-An extended } \\
\text { TAM study. }\end{array}$ \\
\hline Hashim et al. (2015) & Malaysia & $\begin{array}{l}\text { Factors influence the adoption of cloud computing: A comprehensive } \\
\text { review. }\end{array}$ \\
\hline Klug and Bai (2015) & $\begin{array}{l}\text { United States \& } \\
\text { Canada }\end{array}$ & $\begin{array}{l}\text { Factors affecting cloud computing adoption among universities and } \\
\text { colleges in the United States and Canada. }\end{array}$ \\
\hline $\begin{array}{l}\text { Tashkandi and Al-Jabri } \\
\text { (2015) }\end{array}$ & Saudi Arabia & $\begin{array}{l}\text { Cloud Computing Adoption by Higher Education Institutions in Saudi } \\
\text { Arabia }\end{array}$ \\
\hline Wu et al. (2013) & China & $\begin{array}{l}\text { Factors hindering acceptance of using cloud services in university: a } \\
\text { case study. }\end{array}$ \\
\hline Li and Chang (2012) & United States & $\begin{array}{l}\text { A study on user acceptance of cloud computing: A multi-theoretical } \\
\text { perspective. }\end{array}$ \\
\hline
\end{tabular}

\section{LITERATURE RESULTS AND DISCUSSION}

This section presents the findings from the 17 studies that were included in the review. Each paper was analysed following the initial model presented in Figure 1, where each determinant was categorised accordingly. Given the newness of cloud computing in higher education, studies were lacking, hence the inclusion of only 17 studies. Many articles exist in the education sector as a whole, but finding studies relating to cloud adoption determinants in the higher education domain was a challenging process. This could affirm Ercan's statement on the low cloud adoption rates in higher education (4\%) (Ercan, 2010), owing to the hesitation and reluctance in adopting cloud computing in spite of the potential benefits it can offer. 
Table 2. Selected studies related to the criteria

\begin{tabular}{|l|l|l|l|}
\hline \multicolumn{1}{|c|}{ Database } & Total of Research & No. of Excluded Studies & No. of Selected Studies \\
\hline AISeL & 108 & 107 & 1 \\
\hline Emerald & 59 & 56 & 3 \\
\hline IEEE & 58 & 55 & 3 \\
\hline ProQuest & 14 & 12 & 2 \\
\hline Scholar & 131 & 127 & 4 \\
\hline Science Direct & 90 & 88 & 2 \\
\hline Springer & 122 & 120 & 2 \\
\hline Total & 582 & 565 & 17 \\
\hline
\end{tabular}

Figure 1. Proposed model

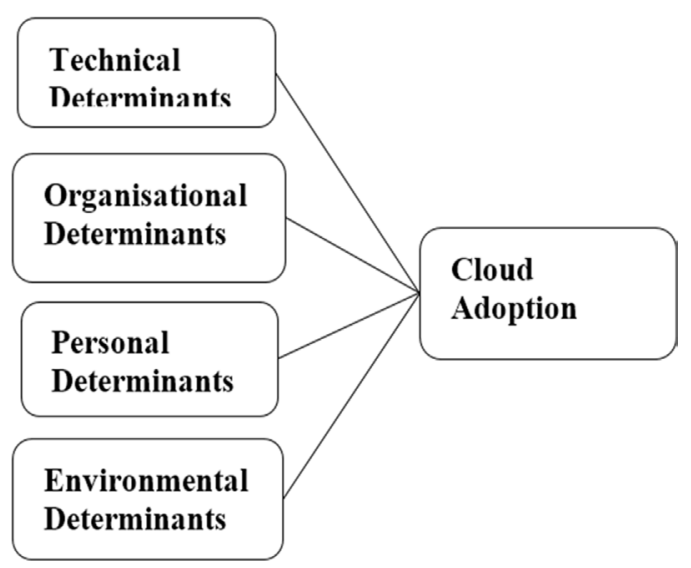

\subsection{Study Characteristics}

Our review demonstrates that the majority of cloud adoption studies focus more on the technological level, followed by the personal level and organisational levels and finally the environmental level. However, most studies looked at the technological aspect as opposed to the wider social aspects of cloud adoption in HEIs. Most of the studies that highlighted technical aspects also highlighted organisational aspects and thus were treated as the same when tallying the instances for each perspective in the included studies. In relation to the SLR results, 51\% of empirical studies use technologicalorganisational levels, $37 \%$ use the individual-level, and only $11 \%$ use the environmental level. Figure 2 illustrates the results.

Furthermore, the most common research models used in the studies were TAM (59\%), TOE (35\%) and DOI (24\%). These findings indicate that most of the cloud adoption literature in the HE domain focus on the decision makers' role in the cloud adoption process and ignore the wider impacts it has on individuals' use of the technology. Therefore, studies emerging from the personal and organisational level are lacking, thus affirming the heavy reliance on technological issues in cloud adoption studies.

Other findings form the SLR indicate that quantitative studies make up $65 \%$ of the included studies, while only $6 \%$ were qualitative studies. In addition, non-empirical studies (e.g. literaturebased studies) made up $29 \%$ of the included studies. Figure 3 illustrates the type of studies included in the SLR. 
Figure 2. Studies utilising each perspective

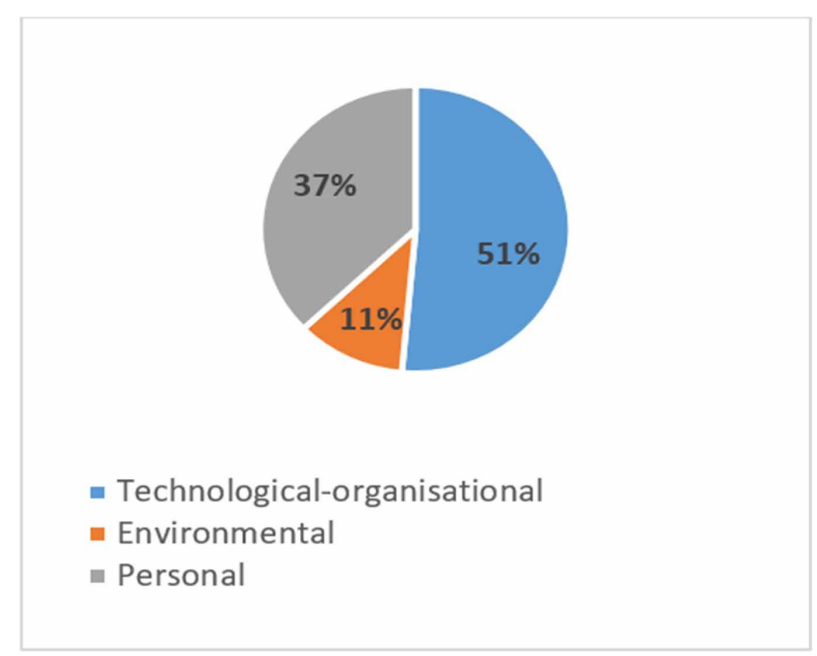

Figure 3. Type of studies

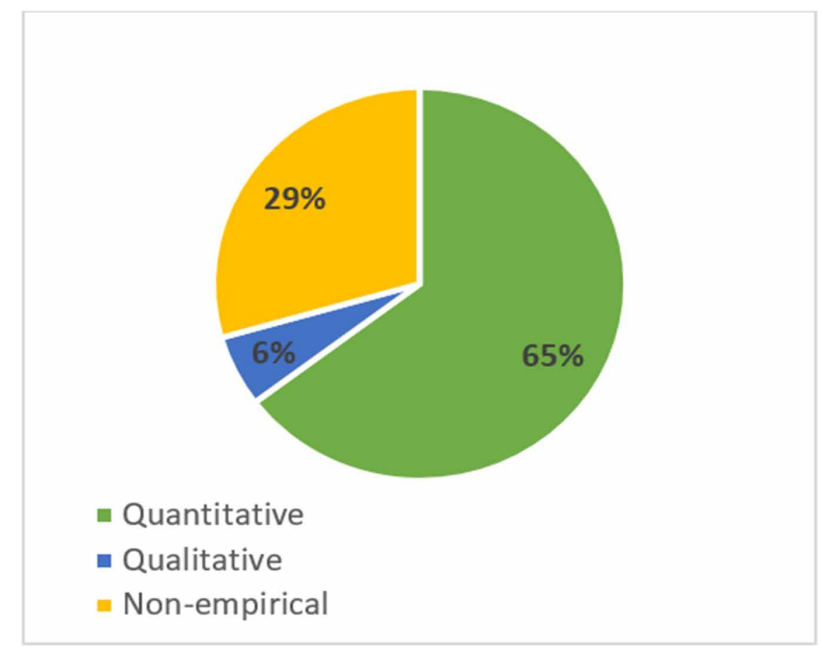

\subsection{Review of Studies}

These results contributed to the development of our cloud adoption model for cloud computing adoption in higher education. The review is divided into four sections based on each perspective (technological, organisational, environmental and personal) (see Table 4 in the Appendix).

\subsubsection{What are the Technical Determinants Contributing to Cloud Computing Adoption in HEls?}

In view of Tornatzky et al. (1990), technological determinants influencing cloud adoption in the organisational context refer to the accessibility and characteristics concerning internal and external technologies. Overall, 30 technological determinants were deduced from the literature (see Table 2). Some of the specific determinants are compatibility, complexity, cost, privacy, relative advantage, reliability, security and trialability, among other innovation characteristics. In particular, numerous 
studies highlight security (59\%) compatibility (47\%), complexity (47\%) relative advantage (41\%) and privacy $(41 \%)$ as the most significant technological determinants influencing cloud adoption in HEIs (Alharthi et al., 2015; Amron et al., 2017; Hashim et al., 2015; Jawad et al., 2017; Klug \& Bai, 2015; Mokhtar et al., 2016; Sabi et al., 2017; Shiau \& Chau, 2016; Tariq et al., 2017; Tashkandi \& Al-Jabri, 2015; Yuvaraj, 2016). However, complexity appears to have a negative influence on cloud computing, but nevertheless should be deliberated in the cloud adoption process given its significance in HEIs' decision to choose cloud as an innovation solution.

Other technological aspects found in the literature include a collection of benefits and challenges of cloud computing. Amongst these determinants, the most significant benefit influencing cloud adoption is reliability (18\%) (Alharthi et al., 2015; Dawson, 2015; Wu et al., 2013), whereas the least significant benefits are availability $(6 \%)$, cost $(6 \%)$, observability $(6 \%)$ and trailability $(6 \%)$ (Sabi et al., 2017; Shiau \& Chau, 2016). Nevertheless, the most significant challenges influencing cloud adoption in HEIs are security and privacy (Alharthi et al., 2015; Hashim et al., 2015; Jawad et al., 2017; Li \& Chang, 2012; Tashkandi \& Al-Jabri, 2015; Wu et al., 2013; Yuvaraj, 2016), reliability (Alharthi et al., 2015; Dawson, 2015; Wu et al., 2013) and trust (Alharthi et al., 2015; Almazroi et al., 2016; Bhatiasevi \& Naglis, 2016; Tariq et al., 2017). Moreover, the challenges outweigh the benefits by quite some margin, thus affirming HEIs' reluctance to adopt cloud computing, as well as the low adoption rates (4\%) within this sector (Ercan, 2010).

As stated previously, the primary studies mostly discussed the technological determinants, which is understandable as these determinants explain the characteristics of the cloud. While many new determinants were deduced from the literature, most came from the DOI and TOE theories (see Table 2). Relative advantage, compatibility, complexity and trialability among other characteristics, such as availability and observability were deduced from the aforementioned models. Furthermore, security, cost, privacy and reliability are new factors deduced from the literature. The results indicated that security, compatibility, complexity, relative advantage and privacy are the most significant technological determinants with security being the most significant (59\%). These findings as consistent with the study of Amron et al. (2017) who concluded that security and privacy concerns have a significant influence on cloud acceptance in University settings.

It is imperative that technological determinants to cloud adoption are not to be understated as proven in the sub-determinants deduced from the literature. These findings are consistent with Kamel (2010) and Demeke et al. (2016) who state that the technological determinants have a significant influence on information systems adoption across various contexts.

Other technological characteristics involve a collection of innovation properties that do align with the aforementioned determinants and sub-determinants, and thus were omitted. In summary, the number of technological determinants as well as the security concerns and relative advantage cloud innovations can bring explains why the technological determinants have the greatest influence on cloud adoption in HEIs.

\subsubsection{What are the Organisational Determinants Contributing to Cloud Computing Adoption in HEls?}

In view of Tornatzky et al. (1990), the organisational context refers to the organisational measures associated with innovation adoption. Overall, 16 organisational determinants were deduced from the literature (see Table 2). Some of the specific determinants are top management support, technology readiness, institution size, institutional culture and internal expertise, among other organisational characteristics. In particular, numerous studies highlight top management support, institutional size (24\% respectively) and IT knowledge/skills/knowledge (18\%) as the most significant organisational determinants influencing cloud adoption in (Alharthi et al., 2015; Amron et al., 2017; Hashim et al., 2015; Jawad et al., 2017; Klug \& Bai, 2015; Mokhtar et al., 2016; Sabi et al., 2017; Shiau \& Chau, 2016; Tariq et al., 2017; Tashkandi \& Al-Jabri, 2015). 
However, some of the organisational determinants were listed as technological determinants (e.g. technological readiness). Since technological determinants focus on technological characteristics and that readiness influences the wider organisational culture (Willcocks et al., 2014), this paper categorised technological readiness as an organisational determinant. Despite this, technological readiness was only discussed in $12 \%$ of the studies included in the review (Amron et al., 2017; Klug $\&$ Bai, 2015), thus calling for the need for more studies that center around technological readiness of cloud computing adoption in HEIs. Other least significant organisational determinants of cloud adoption include organisational culture, internal expertise and lack of control.

A total of 8 secondary adoption factors were deduced from the literature, 7 of which are new. Determinants, such as formalisation and centralisation were combined with organisational culture and organisational size respectively. The rationale for this is that formalisation is a measure of communication and procedures, which is associated with the organisational culture (Tariq et al., 2017). As for centralisation, this centers on the decision-making processes within HEIs, which are subject to the size of the institution (Klug, 2014).

The unique factors deduced from the literature are top management support, technological readiness, organisational culture, and lack of control. The results showed that top management support and organisational size were the most significant organisational determinants, making up $24 \%$ of the total studies respectively, and these findings align with the findings presented by Kandiri and Mugand (2013).

The results also found that culture can significantly influence cloud computing adoption. Innovativeness and attitude towards change, for example, both represent institutional culture. It explains the ways that culture within an institution influence cloud computing adoption. Here, an innovative institution has a positive attitude towards change, and thus is more likely to adopt cloud computing. Clearly, it is important that cloud computing adoption must align with and support an institutional strategy. The findings suggest that while maintaining the cloud environment is handled by the cloud support, it is nevertheless imperative that the adopting institution possesses the internal expertise to help with navigating issues that come with cloud computing. Therefore, prior experience of cloud computing is a significant determinant that should deliberated prior to adopting cloud computing.

\subsubsection{What are the Environmental Determinants Contributing to Cloud Computing Adoption in HEls?}

The environmental context refers to ways in which organisations go about conducting business (Tornatzky et al., 1990). As stated previously, the environmental factor was the least cited in the studies with only 12 environmental determinants being deduced from the literature. In addition, the most significant determinants only represented $18 \%$ of the included studies. Peer pressure despite being one of the most cited determinants is also the most neutral determinant in the sense that it was neither significant nor not significant to influencing the adoption of cloud computing (18\%). However, it still stands as the most significant environmental determinant. Equally, government support, regulatory policies and service provider support are also cited as the most influencing environmental determinants of cloud computing adoption in HEIs (18\% respectively).

The findings also suggest that environmental determinants are vital towards convincing HEIs to adopt cloud computing. Several unique factors were deduced from the literature that were not included in the model studies. Regulation for example is government regulation and national infrastructure which is synonymous with technology support. Peer pressure and physical location are new factors that are not derived from the models used in the studies. Overall, peer pressure, government support, regulatory policies and service provider support are widely cited in the include studies (18\% respectively) (Klug \& Bai, 2015; Mokhtar et al., 2016; Tariq et al., 2017; Tashkandi \& Al-Jabri, 2015).

These equally significant findings point to a correlative relationship between cloud computing adoption and the environment within which it is being adopted (HEIs), and should be researched further. Likewise, the findings suggest a correlation between the national infrastructure (regulatory 
policies) with developing and developed countries, and this is evident in a few studies; e.g. US/ Canada (developed) (Klug \& Bai, 2015) and Saudi Arabia (developing) (Tashkandi \& Al-Jabri, 2015). This demonstrates the gaps in existing technology adoption models, as well as the need to adapt these models before utilising them to explain the issue of innovation adoption to different contexts, particularly higher education.

Cloud computing for example heavily relies on a country's national infrastructure within which the technology is being adopted. The implementation and even before it, accepting cloud technology relies on meeting certain prerequisites, such as the provision of operational telecommunications networks, fast internet connections and stable power supplies (Sabi et al., 2016).

On the other hand, service provider support although not widely cited in the included studies, should not be understated, since the service provider plays an important role in allying potential adopters who have potential issues with cloud-services. This aligns with the technological determinants found in the literature, such as trust and vendor lock-in as these two determinants often decide the adoption of the cloud in organisations (Willcocks et al., 2014). Cloud providers have to earn the adopter's trust though being credible, as well as being readily available and reliable when offering their support. It is also crucial for cloud providers to educate organisations or institutions to be as transparent as possible when it comes to where their data is being stored, in addition to the methods and techniques used to store the data. Therefore, this could help HEIs to overcome any fears or anxieties towards adopting cloud computing.

\subsubsection{What are the Personal Determinants Contributing to Cloud Computing Adoption in HEls?}

Owing to the apparent lack of studies that center on the personal or individualistic perspective of cloud computing adoption, this paper included this perspective for originality purposes and to explore a perspective that is not widely discussed in the existing cloud adoption literature. It is noteworthy to point out that the personal perspective should not be confused with the organisational perspective as this involves determinants that affect the wider institutional practices e.g. top management support and organisational culture, whereas personal determinants affect people or stakeholders that operate within the institution. The personal perspective also considers individuals' influence and power to make adoptive decisions on behalf of the entire institution.

Owing to the significant gap in the personal perspective compared to other perspectives, it was ideal to include this perspective as it holds great importance, since it helps to explore peoples' views and perceptions of innovation adoption. Therefore, including this perspective adds to the originality of the paper as very few studies have covered the role individuals play in cloud adoption within HEIs.

Overall, 20 determinants were deduced from the literature and was the second highest determinant cited in the included studies (37\%). However, the most significant determinants came from the existing models used in the studies with elements of TAM, such as perceived ease of use (PEOU) (65\%) and perceived usage (PU) (59\%), self-efficacy (24\%) and subjective norms (24\%) being the most cited. Nevertheless, several new determinants were deduced from the TAM model among others (see Table 2) (Li \& Chang, 2012; Sabi et al., 2017; Shiau \& Chau, 2016; Yuvaraj, 2016), but represented the least coverage in the studies. New personal determinants deduced from the literature were perceived behavioural control (PBC) (18\%) and attitude (18\%). In particular, PU was also found to be synonymous with the technological determinant relative advantage and PEOU was synonymous with complexity as these determinants appear to sway users' decision to accept the cloud.

Other least significant personal determinants include awareness, competitiveness, external pressures, external support, government pressure, socio-cultural, university location and vendor reputation, all of which were cited in $6 \%$ of the included studies respectively. It was also found that none of the aforementioned determinants correlate with existing knowledge found in the studies and in their respected model, thus indicating new knowledge from the SLR. One perhaps could also 
argue that the attitude towards change from the DOI theory is synonymous with the organisational innovativeness determinant.

Jawad et al. (2017) for example found that innovativeness considerably influences cloud computing adoption in HEIs and that it is linked with individual attitudes towards the cloud. However, no notable individual determinants were found in the study. Nevertheless, these findings from literature do demonstrate that innovativeness and attitudes are both vital to cloud adoption within HEIs, since innovation requires individual perceptions and attitudes towards an innovation in order to make that all-important adoptive decision.

\subsection{Revised Model}

This paper proposes the following adapted model that considers multiple perspectives, such as technological, organisational, environmental and personal determinants that influence cloud adoption. New and existing determinants deduced from the systematic review helped to expand the proposed model. Moreover, the most significant determinants in their respected categories (see Table 3) were

Table 3. Significant factors influencing cloud adoption in HEls

\begin{tabular}{|c|c|c|c|}
\hline Perspective & Determinants & Description & Author(s) \\
\hline \multirow{5}{*}{$\begin{array}{l}\text { Technological } \\
\text { (T) }\end{array}$} & Security & $\begin{array}{l}\text { Degree to which private data is protected within } \\
\text { the cloud. }\end{array}$ & \multirow{5}{*}{$\begin{array}{l}\text { Alharthi et al. (2015); Amron et al. (2017); } \\
\text { Hashim et al. (2015); Jawad et al. (2017); } \\
\text { Klug and Bai (2015); Mokhtar et al. (2016); } \\
\text { Sabi et al. (2017); Shiau and Chau (2016); } \\
\text { Tariq et al. (2017); Tashkandi and Al-Jabri } \\
\text { (2015); Yuvaraj (2016) }\end{array}$} \\
\hline & Compatibility & $\begin{array}{l}\text { Degree to which the cloud can align with the } \\
\text { institution's existing IT infrastructure. }\end{array}$ & \\
\hline & Complexity & $\begin{array}{l}\text { Degree to which the cloud can be difficult to } \\
\text { use and understand }\end{array}$ & \\
\hline & Relative advantage & $\begin{array}{l}\text { Degree to which the cloud is perceived as more } \\
\text { beneficial than its predecessor }\end{array}$ & \\
\hline & Privacy & $\begin{array}{l}\text { Degree to which users' private data remains } \\
\text { secure in the cloud. }\end{array}$ & \\
\hline \multirow{3}{*}{$\begin{array}{l}\text { Organisational } \\
\text { (O) }\end{array}$} & $\begin{array}{l}\text { Top management } \\
\text { support }\end{array}$ & $\begin{array}{l}\text { Top managements' attitude towards supporting } \\
\text { the cloud and the degree of support given } \\
\text { towards its adoption. }\end{array}$ & \multirow{3}{*}{$\begin{array}{l}\text { Alharthi et al. (2015); Amron et al. (2017); } \\
\text { Hashim et al. (2015); Jawad et al. (2017); } \\
\text { Klug and Bai (2015); Mokhtar et al. (2016); } \\
\text { Sabi et al. (2017); Shiau and Chau (2016); } \\
\text { Tariq et al. (2017); Tashkandi and Al-Jabri } \\
\text { (2015) }\end{array}$} \\
\hline & Institution size & $\begin{array}{l}\text { Impact of cloud based on institution size (lager } \\
\text { institutions may require more cloud storage and } \\
\text { services) }\end{array}$ & \\
\hline & $\begin{array}{l}\text { IT experiences/ } \\
\text { knowledge/skills }\end{array}$ & $\begin{array}{l}\text { Degree of cloud expertise among IT managers } \\
\text { and staff. }\end{array}$ & \\
\hline \multirow{4}{*}{$\begin{array}{l}\text { Environmental } \\
\text { (E) }\end{array}$} & Government support & $\begin{array}{l}\text { Degree to which the government supports cloud } \\
\text { projects for higher institutions }\end{array}$ & \multirow{4}{*}{$\begin{array}{l}\text { Klug and Bai (2015); Mokhtar et al. (2016); } \\
\text { Tariq et al. (2017); Tashkandi and Al-Jabri } \\
\text { (2015) }\end{array}$} \\
\hline & Peer pressure & $\begin{array}{l}\text { Degree of influence to adopt the cloud from } \\
\text { members of one's peer group. }\end{array}$ & \\
\hline & Regulatory policies & $\begin{array}{l}\text { Government policies that regulate the cloud } \\
\text { computing market. }\end{array}$ & \\
\hline & $\begin{array}{l}\text { Service provider } \\
\text { support }\end{array}$ & $\begin{array}{l}\text { Degree to which cloud providers offer support } \\
\text { and advice to adopting institutions. }\end{array}$ & \\
\hline \multirow{4}{*}{$\begin{array}{l}\text { Personal } \\
\text { (P) }\end{array}$} & $\begin{array}{l}\text { Perceived Ease Of Use } \\
\text { (PEOU) }\end{array}$ & $\begin{array}{l}\text { Degree to which potential users expect the } \\
\text { cloud to be free of effort. }\end{array}$ & \multirow{4}{*}{$\begin{array}{l}\text { (Li \& Chang, 2012); Sabi et al. (2017); } \\
\text { Shiau and Chau (2016); Yuvaraj (2016) }\end{array}$} \\
\hline & $\begin{array}{l}\text { Perceived Usefulness } \\
\text { (PU) }\end{array}$ & $\begin{array}{l}\text { Degree to which users believe that using the } \\
\text { cloud will enhance their performance. }\end{array}$ & \\
\hline & Self-efficacy & $\begin{array}{l}\text { The personal judgments concerning the } \\
\text { capability of using cloud services in diverse } \\
\text { situations. }\end{array}$ & \\
\hline & Subjective norms & $\begin{array}{l}\text { The social pressure to perform or not perform } \\
\text { a behaviour. }\end{array}$ & \\
\hline
\end{tabular}


included in the model, which in turn demonstrates the most influencing determinants of cloud adoption in HEIs. Figure 4 illustrates the adapted model based on the SLR findings.

\section{CONCLUSION}

Cloud computing is a ubiquitous technological paradigm that offers IT services and centralised resources that reside in the cloud. The majority of tasks currently carried out by the cloud are onlinebased, such as social media communication, email, collaboration, editing and writing documents, watching videos and creating other online content. In our paper, the research trends on cloud adoption is explored. The study explicitly aimed to demonstrate the current research endeavours in cloud adoption in HEIs, determine potential knowledge gaps, identify and categorise determinants influencing cloud adoption into four distinct perspectives and introduce a conceptual model for future direction.

The most influencing technological determinants were security, compatibility, complexity, relative advantage and privacy. For organisational determinants, the most influencing were top management support, institution size and IT experiences/knowledge/skills. For environmental determinants, the most influencing were government support, peer pressure, regulatory policies and service provider support. And for personal determinants, the most influencing were Perceived Ease of Use, Perceived Usefulness, self-efficacy and subjective norms.

On reflection, the key theme of the technological determinants based on the identified determinants is geared towards how the technical aspects of the cloud impact people, and thus there is a clear relationship between the socio-technical aspects of the cloud and they impact people. For the organisational determinants, the main theme geared towards the people involved with running

Figure 4. Final cloud computing adoption model

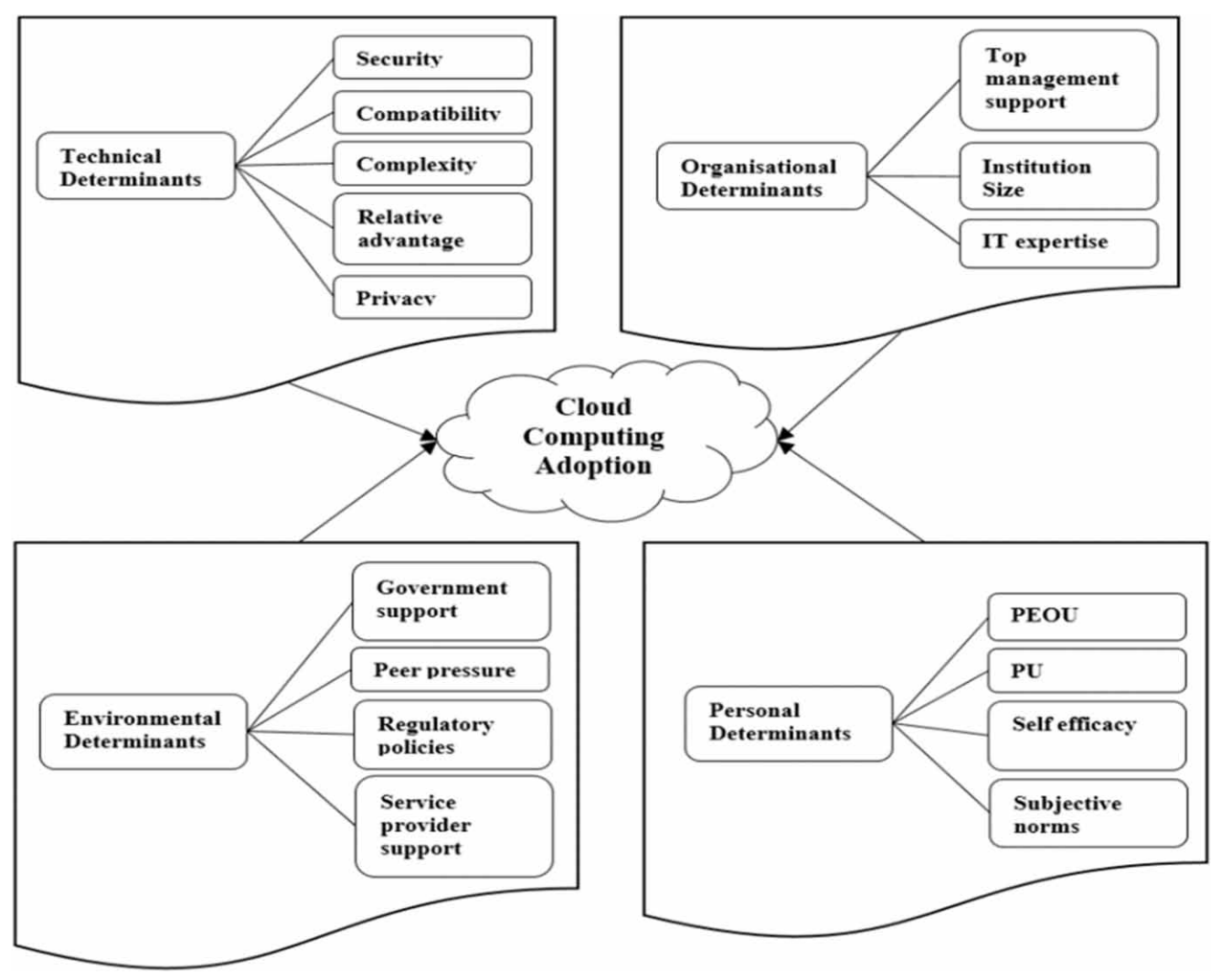


the cloud within HEIs and their degree of competency to maximise the use of the cloud. For the environmental determinants, these geared towards the laws and regulations associated with the cloud that affect both service providers and users. And for the personal determinants, there gears towards the extent of personal and actual use of the cloud in HEI settings.

Moreover, there is a common theme amongst all of the determinant categories, that is, the impact of the cloud on individuals. It can therefore be concluded that the technological, organisational and environmental perspectives are all interrelated with the personal perspective, which highlights the importance of the social-technical aspects of the cloud in HEIs in that HEIs have to look out for not only its interests, but its stakeholder's interests as well.

Despite the low cloud adoption rates in higher education (Ercan, 2010), institutions are starting to adopt the technology. However, there are a lack of studies that identify which significant determinants are convincing HEIs to adopt the cloud. There are numerous determinants that impact the behaviour of decision makers, IT managers, and IT staff in adopting cloud computing, particularly in HEIs. The most influencing factors are identified categorised into four perspectives: technological, organisational, environmental, and personal determinants. The proposed determinants based on the discussion reflect the socio-technical aspects of cloud adoption in HEIs, namely security, complexity, privacy, top management support, IT experiences/knowledge/skills, service provider support and perceived ease of use. All of these determinants have a significant impact on the wider personal or individual perspective of cloud adoption in HEIs, and thus the personal perspective should be researched in further detail in order to obtain a more nuanced approach as many studies only focus on the wider technical or perhaps the organisational perspectives.

Numerous adoption frameworks have been adopted and developed in the existing literature (Gangwar et al., 2015; Jawad et al., 2017; Klug, 2014; Li \& Chang, 2012; Mokhtar et al., 2016; Shiau \& Chau, 2016; Wu et al., 2013), but very few have focused on building a framework for cloud computing adoption in the HEI context. Very few studies also center on the impact of cloud computing adoption on individuals (personal perspective) within HEIs. Our paper endeavoured to fill both gaps by proposing a cloud adoption framework that comprises of the most influencing determinants of cloud computing adoption within HEIs. While there is a greater need for additional research into cloud adoption in the HEI context, this paper has attempted to fill this gap by making a strong contribution to literature by looking at cloud computing adoption in the HEI context from multiple perspectives, namely technological, organisational, environmental and personal.

HEIs can benefit from our paper in terms of the practical contributions in form of out proposed adoption model. HEIs looking to adopt the cloud can use our model to facilitate their decision to adopt the cloud, as well as mitigate potential difficulties they could face throughout the adoption process. Both potential adopters and non-adopters can further benefit from our paper by reviewing our model to make an informed decision to adopt the cloud and suggest whether the cloud is an ideal innovative solution for them.

\subsection{Future Studies}

The findings presented in our paper proves that an HEI's decision to adopt the cloud ultimately comes down to the technology itself, owing to the overwhelming number of significant technological determinants deduced from the SLR. This demonstrates why the relative advantage the cloud can provide plays a significant role in influencing HEIs' adoptive decision. The high prevalence of the technological aspect as opposed to the wider social aspects of cloud adoption in HEIs (organisational and personal perspectives), calls for future studies to be conducted from these significant perspectives. In particular, the personal perspective in order to capture the socio-technical influences of cloud adoption in HEIs.

In addition, some factors were found to have similarities. For example, the environmental determinant service provider support was found to be similar to technological determinants, 
such as trust and vendor lock-in as these two determinants often decide the adoption of the cloud in organisations.

Our paper has discovered a pronounced need for more research into cloud adoption within HEIs. Specifically, additional research into individuals on adoption, in addition to the relationships and correlations between different determinants is recommended. Furthermore, research centering on the application of our model to cloud adoption in the HEI context could be conducted to expand and improve our model based on the study's findings; the adapted model could then be used for other innovations.

Despite our efforts throughout the literature search, this review while comprehensive, the absence of empirical underpinning and the lack of studies in the HEI domain severely limited our study sample to 17 studies. Therefore, it is recommended to empirically test the most significant determinants found in our SLR to unravel additional factors and other reasons why HEIs are adopting cloud computing. 


\section{REFERENCES}

Alharthi, A., Yahya, F., Walters, R. J. \& Wills, G. (2015). An overview of cloud services adoption challenges in higher education institutions.

Almazroi, A. A., Shen, H., Teoh, K.-K., \& Babar, M. A. (2016). Cloud for e-Learning: Determinants of Its Adoption by University Students in a Developing Country. 2016 IEEE 13th International Conference on e-Business Engineering (ICEBE) (pp. 71-78). IEEE.

Ammurathavalli, V., \& Ramesh, V. (2014). Factors Influencing the Adoption of Cloud Computing by Small and Medium-Sized Enterprises (SMEs). International Journal of Engineering, 6(2), 119-125.

Amron, M. T., Ibrahim, R., \& Chuprat, S. (2017). A Review on Cloud Computing Acceptance Factors. Procedia Computer Science.

Armbrust, M., Fox, A., Griffith, R., Joseph, A. D., Katz, R., Konwinski, A., \& Stoica, I. et al. (2010). A View of Cloud Computing. Communications of the ACM, 53(4), 50-58. doi:10.1145/1721654.1721672

Bhatiasevi, V., \& Naglis, M. (2016). Investigating the structural relationship for the determinants of cloud computing adoption in education. Education and Information Technologies, 21(5), 1197-1223. doi:10.1007/ s10639-015-9376-6

Bhatt, C. M., \& Peddoju, S. K. (2016). Cloud Computing Systems and Applications in Healthcare. Hershey, PA: IGI Global.

Bhowmik, S. (2017). Cloud Computing. Cambridge University Press.

Carcary, M., Doherty, E., \& Conway, G. (2014). The Adoption of Cloud Computing by Irish SMEs-an Exploratory Study. Electronic Journal Information Systems Evaluation, 17.

Chang, V. (2015). Delivery and Adoption of Cloud Computing Services in Contemporary Organizations. Hershey, PA: IGI Global. doi:10.4018/978-1-4666-8210-8

Davis, F. D., Bagozzi, R. P., \& Warshaw, P. R. (1989). User acceptance of computer technology: A comparison of two theoretical models. Management Science, 35(8), 982-1003. doi:10.1287/mnsc.35.8.982

Dawson, H. G. (2015). Clearing the clouds: Factors of technology adoption and their relationship to cloud computing adoption in United States higher education-An extended TAM study. Capella University.

Demeke, W., Olden, A., \& Nocera, J. A. (2016). Factors affecting the adoption of information and communication technologies: Small hotels and tour operators in Addis Ababa, Ethiopia. Libri, 66(2), 151-165. doi:10.1515/ libri-2016-0029

Ercan, T. (2010). Effective use of cloud computing in educational institutions. Procedia: Social and Behavioral Sciences, 2(2), 938-942. doi:10.1016/j.sbspro.2010.03.130

Gangwar, H., Date, H., Ramaswamy, R., Irani, Z., \& Irani, Z. (2015). Understanding determinants of cloud computing adoption using an integrated TAM-TOE model. Journal of Enterprise Information Management, 28(1), 107-130. doi:10.1108/JEIM-08-2013-0065

Hashim, H. S., Hassan, Z. B., \& Hashim, A. S. (2015). Factors influence the adoption of cloud computing: A comprehensive review. International Journal of Education and Research, 3(7), 295-306.

Jafari Navimipour, N., \& Charband, Y. (2016). Knowledge sharing mechanisms and techniques in project teams: Literature review, classification, and current trends. Computers in Human Behavior.

Jawad, Z. M., Ajlan, I. K., \& Abdulameer, Z. D. (2017). Cloud Computing Adoption by Higher Education Institutions of Iraq: An Empirical Study. Journal of Education College Wasit University, 1(28), 591-608. doi:10.31185/eduj.Vol1.Iss28.24

Kamel, S. (2010). E-Strategies for Technological Diffusion and Adoption: National ICT Approaches for Socioeconomic Development: National ICT Approaches for Socioeconomic Development. Hershey, PA: IGI Global. doi:10.4018/978-1-60566-388-3 
Kandiri, J., \& Mugand, N. (2013). Determinants of technology innovation implementation effectiveness in higher education institutions. In IST-Africa Conference and Exhibition (IST-Africa) (pp. 1-13). IEEE.

Kim, J., Erdem, M., Byun, J., \& Jeong, H. (2011). Training soft skills via e-learning: International chain hotels. International Journal of Contemporary Hospitality Management, 23(6), $739-763$. doi:10.1108/09596111111153457

Kitchenham, B., \& Charters, S. (2007). Procedures for performing systematic literature reviews in software engineering. Keele University \& Durham University, UK.

Klug, W., \& Bai, X. (2015). Factors affecting cloud computing adoption among universities and colleges in the United States and Canada. Issues in Information Systems, 16(3), 1-10.

Klug, W. E. (2014). The determinants of cloud computing adoption by colleges and universities. Northcentral University.

Li, Y., \& Chang, K.-C. (2012). A study on user acceptance of cloud computing: A multi-theoretical perspective. In Proceedings of the Eighteenth Americas Conference on Information Systems, Seattle, Washington.

Lian, J.-W., Yen, D. C., \& Wang, Y.-T. (2014). An exploratory study to understand the critical factors affecting the decision to adopt cloud computing in Taiwan hospital. International Journal of Information Management, 34(1), 28-36. doi:10.1016/j.ijinfomgt.2013.09.004

Mell, P., \& Grance, T. (2011). The NIST definition of cloud computing. NIST. Retrieved from https://www.nist. gov/sites/default/files/documents/itl/cloud/cloud-def-v15.pdf

Mircea, M., \& Andreescu, A. I. (2011). Using cloud computing in higher education: A strategy to improve agility in the current financial crisis. IBIMA Publishing.

Mokhtar, S. A., Al-Sharafi, A., Ali, S. H. S., \& Aborujilah, A. (2014). Organizational Factors in the Adoption of Cloud Computing in E-learning. In 2014 3rd International Conference on Advanced Computer Science Applications and Technologies (ACSAT) (pp. 188-191). IEEE.

Mokhtar, S. A., Al-Sharafi, A., Ali, S. H. S., \& Al-Othmani, A. Z. (2016). Identifying the determinants of cloud computing adoption in higher education institutions. In International Conference on Information and Communication Technology (ICICTM) (pp. 115-119). IEEE.

Odeh, M., Garcia-Perez, A., \& Warwick, K. (2017). Cloud Computing Adoption at Higher Education Institutions in Developing Countries: A Qualitative Investigation of Main Enablers and Barriers. International Journal of Information and Education Technology, 7(12), 921-927. doi:10.18178/ijiet.2017.7.12.996

Okezie, C., Okafor, K. \& Chidiebele, U. (2012). A Cost Effective Approach To Enterprise Web Application Implementation (A Case For Cloud Erp Web Model).

Rao, R. V., \& Selvamani, K. (2015). Data Security Challenges and Its Solutions in Cloud Computing. Procedia Computer Science.

Rogers, E. M. (2010). Diffusion of Innovations (4th ed.). Free Press.

Sabi, H. M., Uzoka, F.-M. E., Langmia, K., \& Njeh, F. N. (2016). Conceptualizing a model for adoption of cloud computing in education. International Journal of Information Management, 36(2), 183-191. doi:10.1016/j. ijinfomgt.2015.11.010

Sabi, H. M., Uzoka, F.-M. E., Langmia, K., Njeh, F. N., \& Tsuma, C. K. (2017). A cross-country model of contextual factors impacting cloud computing adoption at universities in sub-Saharan Africa. Information Systems Frontiers.

Scholten, J. (2017). The determinants of cloud computing adoption in The Netherlands: a TOE-perspective. University of Twente.

Shana, Z., \& Abulibdeh, E. (2017). Cloud Computing Issues for Higher Education: Theory of Acceptance Model. International Journal of Emerging Technologies in Learning, 12(11), 168-184. doi:10.3991/ijet.v12i11.7473

Shiau, W.-L., \& Chau, P. Y. (2016). Understanding behavioral intention to use a cloud computing classroom: A multiple model comparison approach. Information \& Management, 53(3), 355-365. doi:10.1016/j.im.2015.10.004 
Singh, U., \& Baheti, P. K. (2017). Role and Service of Cloud Computing for Higher Education System. International Research Journal of Engineering and Technology, 4(11), 708-711.

Soltani, Z., \& Navimipour, N. J. (2016). Customer relationship management mechanisms: A systematic review of the state of the art literature and recommendations for future research. Computers in Human Behavior.

Sultan, N. (2010). Cloud computing for education: A new dawn? International Journal of Information Management, 30(2), 109-116. doi:10.1016/j.ijinfomgt.2009.09.004

Sultan, N. A. (2011). Reaching for the "cloud": How SMEs can manage. International Journal of Information Management, 31(3), 272-278. doi:10.1016/j.jinfomgt.2010.08.001

Tariq, M. I., Tayyaba, S., Rasheed, H., \& Ashraf, M. W. (2017). Factors influencing the Cloud Computing adoption in Higher Education Institutions of Punjab, Pakistan. In International Conference on Communication, Computing and Digital Systems (C-CODE) (pp. 179-184). IEEE.

Tashkandi, A., \& Al-Jabri, I. M. (2015). Cloud Computing Adoption by Higher Education Institutions in Saudi Arabia. In 2015 International Conference on Cloud Computing, Riyadh, Saudi Arabia.

Tornatzky, L. G., Eveland, J. D. \& Fleischer, M. (1990). Technological innovation: definitions and perspectives. In The Processes of Technological Innovation (pp. 9-25).

Venkatesh, V., \& Bala, H. (2008). Technology Acceptance Model 3 and a Research Agenda on Interventions. Decision Sciences, 39(2), 273-315. doi:10.1111/j.1540-5915.2008.00192.x

Venkatesh, V., Morris, M. G., Davis, G. B., \& Davis, F. D. (2003). User acceptance of information technology: Toward a unified view. Management Information Systems Quarterly, 27(3), 425-478. doi:10.2307/30036540

Webster, J., \& Watson, R. T. (2002). Analyzing the past to prepare for the future: Writing a. Management Information Systems Quarterly, 26(2), 13-23.

Willcocks, L., Venters, W., \& Whitley, E. (2014). Moving to the Cloud Corporation. Palgrave Macmillan. doi:10.1057/9781137347473

Wu, W.-W., Lan, L. W., \& Lee, Y.-T. (2013). Factors hindering acceptance of using cloud services in university: A case study. The Electronic Library, 31(1), 84-98. doi:10.1108/02640471311299155

Yuvaraj, M. (2016). Determining factors for the adoption of cloud computing in developing countries: A case study of Indian academic libraries. The Bottom Line (New York, N.Y.), 29(4), 259-272. doi:10.1108/BL-02-2016-0009 


\section{APPENDIX}

\section{Table 4. Systematic review}

\begin{tabular}{|c|c|c|c|c|c|c|}
\hline \multirow[b]{2}{*}{ Author } & \multicolumn{4}{|l|}{ Determinants } & \multirow[b]{2}{*}{ Approach } & \multirow[b]{2}{*}{ Results } \\
\hline & $\begin{array}{l}\text { Technological } \\
\text { (T) }\end{array}$ & $\begin{array}{l}\text { Organisational } \\
\text { (O) }\end{array}$ & $\begin{array}{l}\text { Environmental } \\
\text { (E) }\end{array}$ & $\begin{array}{l}\text { Personal } \\
\text { (P) }\end{array}$ & & \\
\hline $\begin{array}{l}\text { Alharthi et } \\
\text { al. (2015) }\end{array}$ & $\begin{array}{l}\text { Bandwidth } \\
\text { Lock-in } \\
\text { Privacy } \\
\text { Reliability } \\
\text { Security } \\
\text { Trust }\end{array}$ & $\begin{array}{l}\text { Acceptance } \\
\text { Top management support }\end{array}$ & - & $\begin{array}{l}\text { PEOU } \\
\text { PU } \\
\text { User training }\end{array}$ & $\begin{array}{l}\text { Method: } \\
\text { None (literature- } \\
\text { based study) } \\
\text { Respondents: } \\
\text { N/A } \\
\text { Theories used: } \\
\text { Technology } \\
\text { Acceptance Model } \\
\text { (TAM). }\end{array}$ & $\begin{array}{l}\text { Important factors were found to be } \\
\text { security, privacy and vendor lock-in that } \\
\text { can affect the adoption of cloud } \\
\text { computing in education but internal } \\
\text { factors such as user's acceptance, user's } \\
\text { trust, Internet efficiency and the } \\
\text { educational management roles can also } \\
\text { impact cloud adoption. }\end{array}$ \\
\hline $\begin{array}{l}\text { Almazroi } \\
\text { et al. } \\
\text { (2016) }\end{array}$ & $\begin{array}{l}\text { Output quality } \\
\text { Trust }\end{array}$ & $\begin{array}{l}\text { Image } \\
\text { Job relevance }\end{array}$ & - & $\begin{array}{l}\text { Anxiety } \\
\text { Behavioural } \\
\text { control } \\
\text { PEOU } \\
\text { Perceived } \\
\text { enjoyment } \\
\text { Playfulness } \\
\text { PU } \\
\text { Self-efficacy } \\
\text { Subjective } \\
\text { norm } \\
\end{array}$ & $\begin{array}{l}\text { Method: } \\
\text { A quantitative } \\
\text { study using } \\
\text { questionnaire } \\
\text { Respondents: } \\
527 \text { University } \\
\text { students } \\
\text { Theories used: } \\
\text { TAM3 }\end{array}$ & $\begin{array}{l}\text { The results reveal that determinants of } \\
\text { PEOU are } \\
\text { ENJ, PLAY, and PEC; PEOU, REL, and } \\
\text { TR predict PU; SN determines IMG only; } \\
\text { and PEOU and PU predict BI. }\end{array}$ \\
\hline $\begin{array}{l}\text { Amron et } \\
\text { al. (2017) }\end{array}$ & $\begin{array}{l}\text { Bandwidth } \\
\text { Compatibility } \\
\text { Complexity } \\
\text { Relative } \\
\text { advantage } \\
\text { Security }\end{array}$ & $\begin{array}{l}\text { IT } \\
\text { experiences/knowledge/skills } \\
\text { Technology readiness } \\
\text { Top management support }\end{array}$ & $\cdot$ & $\begin{array}{l}\text { Human } \\
\text { readiness } \\
\text { Interaction and } \\
\text { feedback }\end{array}$ & $\begin{array}{l}\text { Method: } \\
\text { None (literature- } \\
\text { based study) } \\
\text { Respondents: } \\
\text { N/A } \\
\text { Theories used: } \\
\text { Technology, } \\
\text { organisational and } \\
\text { environmental } \\
\text { (TOE) model }\end{array}$ & $\begin{array}{l}\text { Important factors were found to be } \\
\text { security, complexity, compatibility, } \\
\text { bandwidth, top management support, IT } \\
\text { knowledge, interaction/feedback and } \\
\text { technological readiness. }\end{array}$ \\
\hline
\end{tabular}

\begin{tabular}{|c|c|c|c|c|c|c|}
\hline & & & & & $\begin{array}{l}\text { Diffusion of } \\
\text { Innovation (DOI) } \\
\text { model }\end{array}$ & \\
\hline $\begin{array}{l}\text { Bhatiasevi } \\
\text { and Naglis } \\
\text { (2016) }\end{array}$ & $\begin{array}{l}\text { Convenience } \\
\text { Perceived } \\
\text { Functionality } \\
\text { Software } \\
\text { Trust }\end{array}$ & $\cdot$ & $\cdot$ & $\begin{array}{l}\text { PEOU } \\
\text { PU } \\
\text { Subjective } \\
\text { norm } \\
\text { Self-efficacy }\end{array}$ & $\begin{array}{l}\text { Method: } \\
\text { A quantitative } \\
\text { study using } \\
\text { questionnaire } \\
\text { Respondents: } \\
393 \text { from Mahidol } \\
\text { university } \\
\text { international } \\
\text { colleges and } \\
\text { Thammasat } \\
\text { university in } \\
\text { Thailand. } \\
\text { Theories used: } \\
\text { Technology } \\
\text { Acceptance Model } \\
\text { (TAM). }\end{array}$ & $\begin{array}{l}\text { The results showed that PU, PEOU } \\
\text { Perceived Convenience, Trust, Software } \\
\text { Functionality have a positive relationship } \\
\text { to intention to adopt cloud computing. }\end{array}$ \\
\hline $\begin{array}{l}\text { Dawson } \\
\text { (2015) }\end{array}$ & $\begin{array}{l}\text { Perceived } \\
\text { security } \\
\text { Perceived } \\
\text { Reliability } \\
\text { Perceived } \\
\text { benefits }\end{array}$ & - & - & $\begin{array}{l}\text { PU } \\
\text { PEOU }\end{array}$ & $\begin{array}{l}\text { Method: } \\
\text { A quantitative } \\
\text { study using } \\
\text { Questionnaire } \\
\text { Respondents: } \\
217 \text { higher } \\
\text { education in USA } \\
\text { Theories used: } \\
\text { Technology } \\
\text { Acceptance Model } \\
\text { (TAM). }\end{array}$ & $\begin{array}{l}\text { The results showed that all factors have a } \\
\text { significant correlation to cloud computing } \\
\text { adoption. }\end{array}$ \\
\hline $\begin{array}{l}\text { Hashim et } \\
\text { al. (2015) }\end{array}$ & $\begin{array}{l}\text { Compatibility } \\
\text { Complexity } \\
\text { Privacy } \\
\text { Relative } \\
\text { advantage }\end{array}$ & $\cdot$ & $\cdot$ & $\begin{array}{l}\text { PEOU } \\
\text { PU }\end{array}$ & $\begin{array}{l}\text { Method: } \\
\text { None (literature- } \\
\text { based study) } \\
\text { Respondents: }\end{array}$ & $\begin{array}{l}\text { The results showed that all factors have a } \\
\text { significant correlation to cloud computing } \\
\text { adoption. }\end{array}$ \\
\hline
\end{tabular}


Table 4. Continued

\begin{tabular}{|c|c|c|c|c|c|c|}
\hline & Security & & & & $\begin{array}{l}\text { N/A } \\
\text { Theories used: } \\
\text { TAM } \\
\text { DOI, } \\
\text { UTAUT } \\
\text { TOE }\end{array}$ & \\
\hline $\begin{array}{l}\text { Jawad et al. } \\
\text { (2017) }\end{array}$ & $\begin{array}{l}\text { Relative } \\
\text { advantage } \\
\text { Complexity } \\
\text { Security } \\
\text { Privacy }\end{array}$ & $\begin{array}{l}\text { Top management support } \\
\text { Innovativeness } \\
\text { IT } \\
\text { experiences/knowledge/skills }\end{array}$ & $\begin{array}{l}\text { Competiveness } \\
\text { External support }\end{array}$ & $\cdot$ & $\begin{array}{l}\text { Method: } \\
\text { A quantitative } \\
\text { study using } \\
\text { Questionnaire } \\
\text { Respondents: } \\
104 \text { respondents } \\
\text { divided as (61) } \\
\text { academic staff, and } \\
\text { (43) non-academic } \\
\text { staff } \\
\text { Theories used: } \\
\text { TOE }\end{array}$ & $\begin{array}{l}\text { The findings indicated that Relative } \\
\text { Advantage, Security and Privacy of using } \\
\text { the cloud computing services, the } \\
\text { complexity of usages, Innovativeness, and } \\
\text { external support are most effecting factors } \\
\text { of adopting cloud computing. On the } \\
\text { other hand, the top management support, } \\
\text { IT experience, and competitive are not } \\
\text { significant factors of adopting cloud } \\
\text { computing. }\end{array}$ \\
\hline $\begin{array}{l}\text { Klug and } \\
\text { Bai (2015) }\end{array}$ & $\begin{array}{l}\text { Compatibility } \\
\text { Complexity } \\
\text { Relative } \\
\text { advantage }\end{array}$ & $\begin{array}{l}\text { Institution size } \\
\text { Perceived barriers } \\
\text { Technology readiness }\end{array}$ & $\begin{array}{l}\text { Regulatory } \\
\text { polices } \\
\text { Service provider } \\
\text { support }\end{array}$ & - & $\begin{array}{l}\text { Method: } \\
\text { A quantitative } \\
\text { study using } \\
\text { questionnaire } \\
\text { Respondents: } \\
119 \text { CIO and IT } \\
\text { managers in U.S } \\
\text { universities } \\
\text { Theories used: } \\
\text { Technological, } \\
\text { Organizational and } \\
\text { Environmental } \\
\text { (TOE) framework }\end{array}$ & $\begin{array}{l}\text { The findings showed that all factors are } \\
\text { statistically significant in determining } \\
\text { cloud computing adoption except relative } \\
\text { advantage, regulatory policy, and service } \\
\text { provider support. }\end{array}$ \\
\hline \multirow[t]{2}{*}{$\begin{array}{l}\text { Li and } \\
\text { Chang } \\
(2012)\end{array}$} & $\begin{array}{l}\text { Privacy } \\
\text { concerns }\end{array}$ & Transfer skill & $\begin{array}{l}\text { Vendor } \\
\text { reputation }\end{array}$ & $\begin{array}{l}\text { Attitude } \\
\text { PEOU }\end{array}$ & $\begin{array}{l}\text { Method: } \\
\text { A quantitative } \\
\text { study using }\end{array}$ & $\begin{array}{l}\text { The results shows that a person's attitude } \\
\text { toward cloud applications, subjective } \\
\text { norm, and perceived behavioural control }\end{array}$ \\
\hline & $\begin{array}{l}\text { Security } \\
\text { concerns } \\
\text { Vendor lock-in }\end{array}$ & & & $\begin{array}{l}\text { Perceived } \\
\text { behavioural } \\
\text { control (PBC) } \\
\text { PU } \\
\text { Subjective } \\
\text { norm } \\
\text { Voluntariness }\end{array}$ & $\begin{array}{l}\text { questionnaire } \\
\text { Respondents: } \\
225 \text { students at a } \\
\text { leading private } \\
\text { University in } \\
\text { Taiwan. } \\
\\
\text { Theories used: } \\
\text { Theory Planned } \\
\text { Behaviour (TPB). } \\
\text { Technology } \\
\text { Acceptance Model } \\
\text { (TAM). }\end{array}$ & $\begin{array}{l}\text { have direct impacts on the person's } \\
\text { behavioural intention to use the } \\
\text { applications. Meanwhile, privacy and } \\
\text { security concerns, concerns about vendor } \\
\text { lock-in, perceived vendor reputation, } \\
\text { perceived usefulness, perceived ease of } \\
\text { use, and perceived transferability of } \\
\text { previously learned computer skills, have } \\
\text { indirect impacts on behavioural intention. }\end{array}$ \\
\hline $\begin{array}{l}\text { Mokhtar et } \\
\text { al. (2016) }\end{array}$ & $\begin{array}{l}\text { Relative } \\
\text { advantage } \\
\text { Complexity } \\
\text { Compatibility }\end{array}$ & $\begin{array}{l}\text { Top management support } \\
\text { Institution size } \\
\text { Adoption plan }\end{array}$ & $\begin{array}{l}\text { Service provider } \\
\text { support } \\
\text { Government } \\
\text { support }\end{array}$ & - & $\begin{array}{l}\text { Method: } \\
\text { A quantitative } \\
\text { study using } \\
\text { questionnaire } \\
\text { Respondents: } \\
217 \text { accredited } \\
\text { HEIs in Malaysia } \\
\text { Theories used: } \\
\text { TOE }\end{array}$ & \\
\hline $\begin{array}{l}\text { Sabi et al. } \\
\text { (2017) }\end{array}$ & $\begin{array}{l}\text { Compatibility } \\
\text { Complexity } \\
\text { Cost } \\
\text { Data security } \\
\text { Infrastructure } \\
\text { Observability } \\
\text { Relative } \\
\text { advantage } \\
\text { Result } \\
\text { demonstrable } \\
\text { Risk } \\
\text { Trailability } \\
\text { Data security } \\
\text { Infrastructure } \\
\end{array}$ & $\begin{array}{l}\text { Institution age } \\
\text { Institution size }\end{array}$ & $\begin{array}{l}\text { Awareness } \\
\text { Socio-cultural } \\
\text { University } \\
\text { location }\end{array}$ & $\begin{array}{l}\text { Individual age } \\
\text { Perceived } \\
\text { Perceived } \\
\text { Use (PEOU) } \\
\text { Usefulness } \\
\text { (PU) }\end{array}$ & $\begin{array}{l}\text { Method: } \\
\text { A quantitative } \\
\text { questionnaire } \\
\text { Respondents: } \\
355 \text { respondents } \\
\text { from public and } \\
\text { private universities } \\
\text { countries (Nigeria, } \\
\text { and Uganda), as } \\
\text { well as members } \\
\text { of the Association } \\
\text { of } \\
\text { Information }\end{array}$ & $\begin{array}{l}\text { The results show that data security, result } \\
\text { demonstrable, usefulness, Socio-cultural, } \\
\text { age of university, size of university, and } \\
\text { individual age have significant effect on } \\
\text { intent to adopt cloud computing. }\end{array}$ \\
\hline
\end{tabular}




\section{Table 4. Continued}

\begin{tabular}{|c|c|c|c|c|c|c|}
\hline & & & & & \begin{tabular}{|l|} 
African Chapter \\
(AISSAC). \\
Theories used: \\
Diffusion of \\
Innovation (DOI) \\
Technology \\
(TAM). \\
\end{tabular} & \\
\hline $\begin{array}{l}\text { Shana and } \\
\text { Abulibdeh } \\
\text { (2017) }\end{array}$ & - & - & - & $\begin{array}{l}\text { Actual use } \\
\text { Intention to } \\
\text { use } \\
\text { PEOU } \\
\text { Perceived } \\
\text { behavioural }\end{array}$ & \begin{tabular}{|l|} 
Method: \\
A quantitative \\
questionnaire \\
\\
Respondents: \\
239 preservice \\
teachers and \\
undergraduate \\
students. \\
Theories used: \\
TAM
\end{tabular} & $\begin{array}{l}\text { Only perceived ease of use will affect pre- } \\
\text { service teachers' use of cloud computing } \\
\text { in the future. In higher learning, perceived } \\
\text { usefulness in cloud computing is } \\
\text { insufficient to influence pre-service } \\
\text { teachers to use cloud computing, unless } \\
\text { they know the applications and } \\
\text { understand how to use the technology. }\end{array}$ \\
\hline $\begin{array}{l}\text { Shiau and } \\
\text { Chau } \\
\text { (2016) }\end{array}$ & $\begin{array}{l}\text { Applications } \\
\text { service quality } \\
\text { Cloud service } \\
\text { Compatibility } \\
\text { quality } \\
\text { Result } \\
\text { demonstrable } \\
\text { Trialability } \\
\text { Visibility }\end{array}$ & - & - & $\begin{array}{l}\text { Attitude } \\
\text { Cloud self } \\
\text { efficacy } \\
\text { PBC } \\
\text { PEOU } \\
\text { PP } \\
\text { PU } \\
\text { Self-efficacy } \\
\text { Subjective } \\
\text { norms } \\
\text { Voluntariness }\end{array}$ & \begin{tabular}{|l} 
Method: \\
A quantitative \\
study using \\
questionnaire \\
Respondents: \\
478 students at \\
medium size \\
university in \\
Taiwan \\
\\
Theories used: \\
Service Quality \\
Model (SQ). \\
Motivational \\
Model (MM). \\
Technology \\
Acceptance Model \\
(TAM).
\end{tabular} & $\begin{array}{l}\text { The results found that all factors have } \\
\text { significantly positive effects on the } \\
\text { intention to use cloud computing }\end{array}$ \\
\hline
\end{tabular}

\begin{tabular}{|c|c|c|c|c|c|c|}
\hline & & & & & $\begin{array}{l}\text { Theory of Reason } \\
\text { Action(TRA) } \\
\text { Theory of Planed } \\
\text { Behaviour (TPB). } \\
\text { Innovation } \\
\text { diffusion Theory } \\
\text { (IDT) }\end{array}$ & \\
\hline $\begin{array}{l}\text { Tariq et al. } \\
(2017)\end{array}$ & $\begin{array}{l}\text { Affordability } \\
\text { Compatibility } \\
\text { Complexity } \\
\text { Confidentiality } \\
\text { Quality of } \\
\text { service } \\
\text { Security } \\
\text { Trust }\end{array}$ & $\begin{array}{l}\text { Cost Training } \\
\text { IT } \\
\text { experiences/knowledge/skills } \\
\text { Institutional culture } \\
\text { Institution size }\end{array}$ & $\begin{array}{l}\text { Government } \\
\text { pressure } \\
\text { External } \\
\text { pressures } \\
\text { Peer pressure }\end{array}$ & - & $\begin{array}{l}\text { Method: } \\
\text { A quantitative } \\
\text { study using } \\
\text { questionnaire } \\
\text { Respondents: } \\
900 \text { students of } \\
\text { Higher Education } \\
\text { Institutions of } \\
\text { Punjab, Pakistan } \\
\text { Theories used: } \\
\text { TOE }\end{array}$ & $\begin{array}{l}\text { External Pressure, Confidentiality, Loss } \\
\text { of Governance, Government Support and } \\
\text { Skilled end-use are important and } \\
\text { influential factors in the adoption of cloud } \\
\text { computing in HEIs and have statistically } \\
\text { lower adoption attitude. }\end{array}$ \\
\hline $\begin{array}{l}\text { Tashkandi } \\
\text { and Al- } \\
\text { Jabri } \\
(2015)\end{array}$ & $\begin{array}{l}\text { Compatibility } \\
\text { Complexity } \\
\text { Privacy } \\
\text { Concerns } \\
\text { Relative } \\
\text { advantage } \\
\text { Vendor lock-in }\end{array}$ & $\begin{array}{l}\text { Top management } \\
\text { support }\end{array}$ & $\begin{array}{l}\text { Government } \\
\text { support } \\
\text { Peer pressure } \\
\text { pressure } \\
\text { Regulatory } \\
\text { policies }\end{array}$ & - & $\begin{array}{l}\text { Method: } \\
\text { A quantitative } \\
\text { study using } \\
\text { Questionnaire } \\
\text { Respondents: } \\
33 \text { responses of IT } \\
\text { decision makers in } \\
\text { higher education in } \\
\text { KSA. } \\
\text { Theories used: } \\
\text { Technological, } \\
\text { Organizational and } \\
\text { Environmental } \\
\text { (TOE) }\end{array}$ & $\begin{array}{l}\text { Three Factors were found significant in } \\
\text { this context study: Relative Advantage, } \\
\text { Data Privacy and Complexity are the most } \\
\text { significant factors. }\end{array}$ \\
\hline \multirow[t]{2}{*}{$\begin{array}{l}\text { Wu et al. } \\
\text { (2013) }\end{array}$} & $\begin{array}{l}\text { Control } \\
\text { Privacy } \\
\text { Reliability }\end{array}$ & $\begin{array}{l}\text { Training, Organisational } \\
\text { support }\end{array}$ & - & $\begin{array}{l}\text { Behavioural } \\
\text { intention } \\
\text { PEOU }\end{array}$ & $\begin{array}{l}\text { Method: } \\
\text { A qualitative case } \\
\text { study of university }\end{array}$ & $\begin{array}{l}\text { Based on the findings, the case university } \\
\text { is suggested to exercise necessary } \\
\text { intervention activities (such as training. }\end{array}$ \\
\hline & $\begin{array}{l}\text { Security } \\
\text { Vendor lock }\end{array}$ & & & $\begin{array}{l}\text { Perceived } \\
\text { satisfaction } \\
\text { PU } \\
\text { Interaction and } \\
\text { feedback } \\
\text { Peer support }\end{array}$ & $\begin{array}{l}\text { Respondents: } \\
\text { University students } \\
\\
\text { Theories used: } \\
\text { DEMATEL } \\
\text { (decision making } \\
\text { trial and evaluation } \\
\text { laboratory) } \\
\text { TAM } \\
\end{array}$ & $\begin{array}{l}\text { organisational support, and peers' } \\
\text { support) to enhance the level of } \\
\text { acceptance of this newly introduced } \\
\text { internal cloud solutions. }\end{array}$ \\
\hline $\begin{array}{l}\text { Yuvaraj } \\
\text { (2016) }\end{array}$ & $\begin{array}{l}\text { Availability } \\
\text { Privacy risk } \\
\text { Scalability } \\
\text { Security risk }\end{array}$ & Return on time & - & $\begin{array}{l}\text { Perceived } \\
\text { Usefulness } \\
\text { (PU) } \\
\text { Perceived Ease } \\
\text { Of Use } \\
\text { (PEOU) } \\
\text { Attitude }\end{array}$ & $\begin{array}{l}\text { Method: } \\
\text { A quantitative } \\
\text { study using } \\
\text { questionnaire } \\
\\
\text { Respondents: } \\
\text { Library } \\
\text { professionals in } 28 \\
\text { central Universities } \\
\text { in India. } \\
\text { Theories used: } \\
\text { Technology } \\
\text { Acceptance Model } \\
\text { (TAM). }\end{array}$ & $\begin{array}{l}\text { The results show that PEOU, PU and } \\
\text { availability have a significant impact on } \\
\text { behavioural intention to adopt cloud } \\
\text { computing in libraries. }\end{array}$ \\
\hline
\end{tabular}


Mohammed Ali is a lecturer of information systems who has an emerging profile in the areas of Cloud Computing, Enterprise Resource Planning, and Virtual learning systems. He recently published in the journal of International Journal of Enterprise Information Systems (IJEIS), and the British Academy of Management Proceedings. He is currently investigating the area of Cloud Computing Applications In Higher Education, including different technical, organisational, and political issues associated with its adoption. 